Department of Neuroanatomy (Prof. N. Shimizu), Institute of Higher Nervous Activity, Osaka University Medical School, Osaka, Japan

\title{
Histochemical Changes in the Mesencephalic Nucleus and Motor Nucleus Following Neurotomy of the Third Division of the Trigeminal Nerve*
}

\author{
Kikuko Імамото
}

Received October 2, 1971

\begin{abstract}
Summary. Following unilateral section of the trigeminal third division, the ipsilateral mesencephalic neurons showed severe shrinkage with central chromatolysis and nuclear eccentricity while the motor neurons showed mild swelling. Histochemical reactions in the mesencephalic neurons were mostly characterized by the decreased activity of phosphorylase after $16 \mathrm{hrs}$ and concomitant diminution of PAS-positive substances. The increased activities of G6PDH and ACP were recognized in almost all neurons of both nuclei and in adjacent neuroglial cells. The neuropil in the motor nucleus showed remarkable decrease of SDH, ALD and LDH activities after 10 days. The results obtained were discussed in relation to chromatolysis, protein synthesis and carbohydrate metabolism in the affected neurons and surrounding neuropil.
\end{abstract}

The relation of the monosynaptic reflex arc between the mesencephalic nucleus and motor nucleus is well known in masticatory function (SzENTÁGOTHAI, 1948; SMITH et al., 1967, 1968). The closely connected nuclei of the trigeminal nerve show some histochemical characteristics different from or similar to each other (ABE and Shimizu, 1964; Nakajima, 1965; MaedA, 1966; Shimizu and Abe, 1966). Based on the recent findings concerning these nuclei, it was attempted to observe histochemical as well as morphological changes in the affected neurons following section of the trigeminal third division. As mentioned by GEIST (1933), CRAGG (1970) and others, some experimental factors may cause considerable inconsistency in axonal reactions under morphological and histochemical studies. In this study, however, it was considered that different changes between proprioceptive and motor neurons after trigeminal nerve section should be more or less attributed to the functional and metabolic peculiarities of each nucleus. From the histochemical viewpoint, some interesting results were obtained in enzyme reactions concerning carbohydrate metabolism. A comparison of the changes in both nuclei may serve to explain the different metabolic changes following section of either dendrites or axons.

\section{Material and Method}

In this study 79 albino rats weighing between $150-200 \mathrm{~g}$ were used. The third division of the trigeminal nerve was cut and about $1 \mathrm{~mm}$ of its distal stump was removed below the foramen ovale in the left side. This operation was performed under nembutal anethesia. The treated animals were given a supply of soft food because of disordered mastication.

* This study was supported by Scientific Research Grants of the Japanese Ministry of Education (No. 90425, No. 90460). 
After various periods ranging from 3 hrs to 80 days these rats were sacrificed. Some animals were perfused with Orth's solution and the excised brains were postfixed with Rossman's fixative for the paraffin sections. A series of the brain sections of about $15 \mu$ thickness were routinely subjected to Nissl staining (Gallocyanin) and periodic acid Shiff reaction (PAS) following occasional amylase digestion. The brains of others were prepared for the fresh-frozen sections of 15 to $20 \mu$ in thickness, which were used for the enzyme reactions. Special attention was paid to the alterations of activities such as phosphorylase (PHO), UDPG-glycogen transferase (UDPGGT), aldolase (ALD), lactic dehydrogenase (LDH), glucose-6-phosphate dehydrogenase (G6PDH), succinic dehydrogenase (SDH) and acid phosphatase (ACP). Each technique employed was as follows: TAKEUCHI method for PHO (1962), TAKEUCHI and Glenner method for UDPGGT (1960), ABE and SHimizu method for ALD (1964), Nachalas et al. method for SDH (1957), Nachalas et al. method for G6PDH and LDH (1958) and SHIMIzU and ARIzono method for ACP (1949).

\section{Results}

\section{A. General figures in the mesencephalic and motor nuclei of rats}

The mesencephalic neurons are pseudounipolar and easily divided into three types: small, medium-sized and large cells, as described by MAEDA (1966) and IмAмото and SHimizu (1970). Generally the Nissl substances in these neurons are fine granular, differing from the typical tigroid bodies in the trigeminal motor neurons. The cytoplasmic matrix of the medium-sized and small neurons is more basophilic than that of large ones. The trigeminal motor nucleus is composed of large and multipolar neurons similar to the anterior horn cells of the spinal cord.

PAS reaction shows contrast in both nuclei, that is, the mesencephalic neurons are distinctly positive and the motor neurons are very weakly positive. It demonstrated that there are small granular products throughout the cytoplasm of the mesencephalic neurons especially in the medium-sized ones. Also coarse granular products often appeared, adhering to the external surface of the neurons. In the neuropil adjacent to the mesencephalic neurons, PAS reaction is negligible while it is considerably positive in the neuropil of the motor nucleus, which shows very fine particles.

As for enzyme activities such as PHO, UDPGGT and G6PDH, there is a marked difference between the mesencephalic nucleus and motor nucleus. PHO reaction is most intense in the medium-sized or small neurons of the mesencephalic nucleus and nearly in parallel with the intensity of the PAS reaction. It shows various reaction colors ranging from pale purple to dark blue with iodine solution, corresponding to the structure of synthesized polyglucose. In the motor nucleus the neuropil also shows weak or moderate purple color of PHO reaction as well as neurons. UDPGGT activity shows brown to red color with iodine solution in the mesencephalic neurons, while it is negative or weak in the motor neurons. On the contrary, the motor neurons show much stronger activity of G6PDH than the mesencephalic neurons. It is rather characteristic that almost all the mesencephalic neurons show extremely weak G6PDH reaction. ALD and LDH activities are much stronger in both the sensory and motor neurons of the trigeminal nerve. The motor neurons, however, show slightly lower activity of SDH than the mesencephalic neurons. The neuropil 
of the motor nucleus exhibits considerably high activities in ALD, LDH and SDH preparations, though the neuropil surrounding the mesencephalic neurons is negative in each reaction. In addition to these enzyme reactions, intense activity of ACP is also found to be granular type in the mesencephalic neurons and reticular type in the motor neurons.
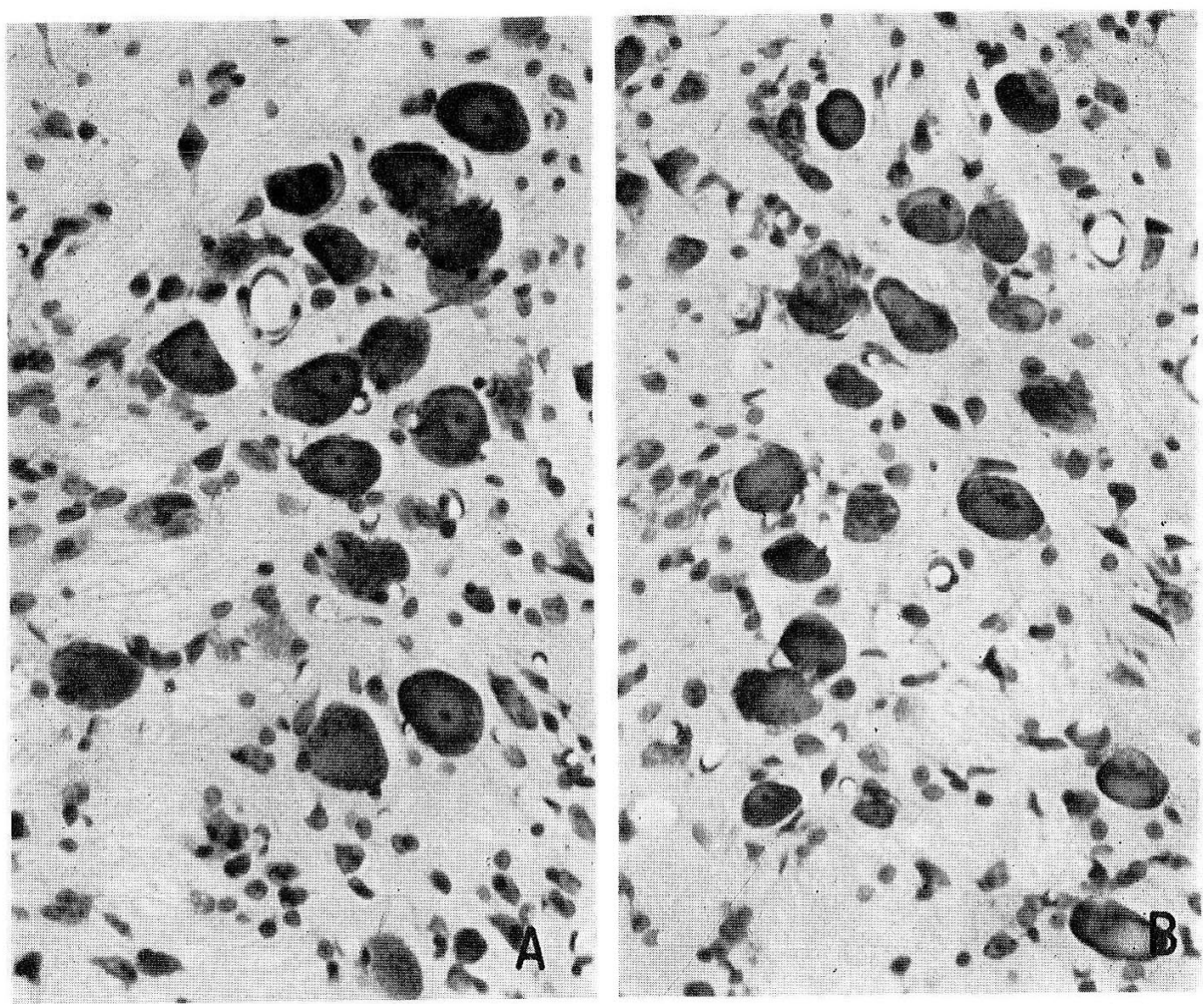

Fig. 1. Mesencephalic nucleus, 2 days after neurotomy of the trigeminal third division. A shows the control side and $\mathbf{B}$ the affected side. Gallocyanin stain. $\times 225$

\section{B. Changes in the mesencephalic nucleus following neurotomy}

Experimental changes in the mesencephalic neurons were first recognized by the alteration of PHO activity and subsequently by the diminution of PAS-positive substances in the affected side. As soon as the peripheral nerves were cut, PHO was distinctly activated in the mesencephalic neurons. PHO activity reached maximal intensity after 6 hrs on the affected side. However, the temporarily activated PHO was suddenly decreased after 16 hrs. As shown in Figure 3B, only a few small neurons were positive in dark blue color. During this early period, PAS reaction was also severely altered concomitant with PHO activity in the ipsilateral side. PAS positive substances were fully preserved in the perikaryon for about 6 hrs but not visible after 16 hrs (Fig. 2). At the same time, PAS positive coarse granules also disappeared from the outer surface of the mesencephalic neurons, though only a few small neurons showed diffuse PAS positive reaction. The Nissl preparations of this 
period showed slight changes, being somewhat hyperchromic compared with the control. In regard to UDPGGT, $\mathrm{ALD}, \mathrm{LDH}$ and $\mathrm{SDH}$, it was difficult to recognize the changes in the activities during the early period. ACP reaction was distinctly increased and G6PDH reaction slightly increased in the perinuclear area of the affected neurons after $16 \mathrm{hrs}$. The Nissl bodies gradually became smaller in size until they appeared as dust-like particles or as optically homogenous after $24 \mathrm{hrs}$. In the next period of 2 to 4 days, serious morphological changes were seen in the mesencephalic neurons (Fig. 1). The neurons, which were temporarily hyperchromic,
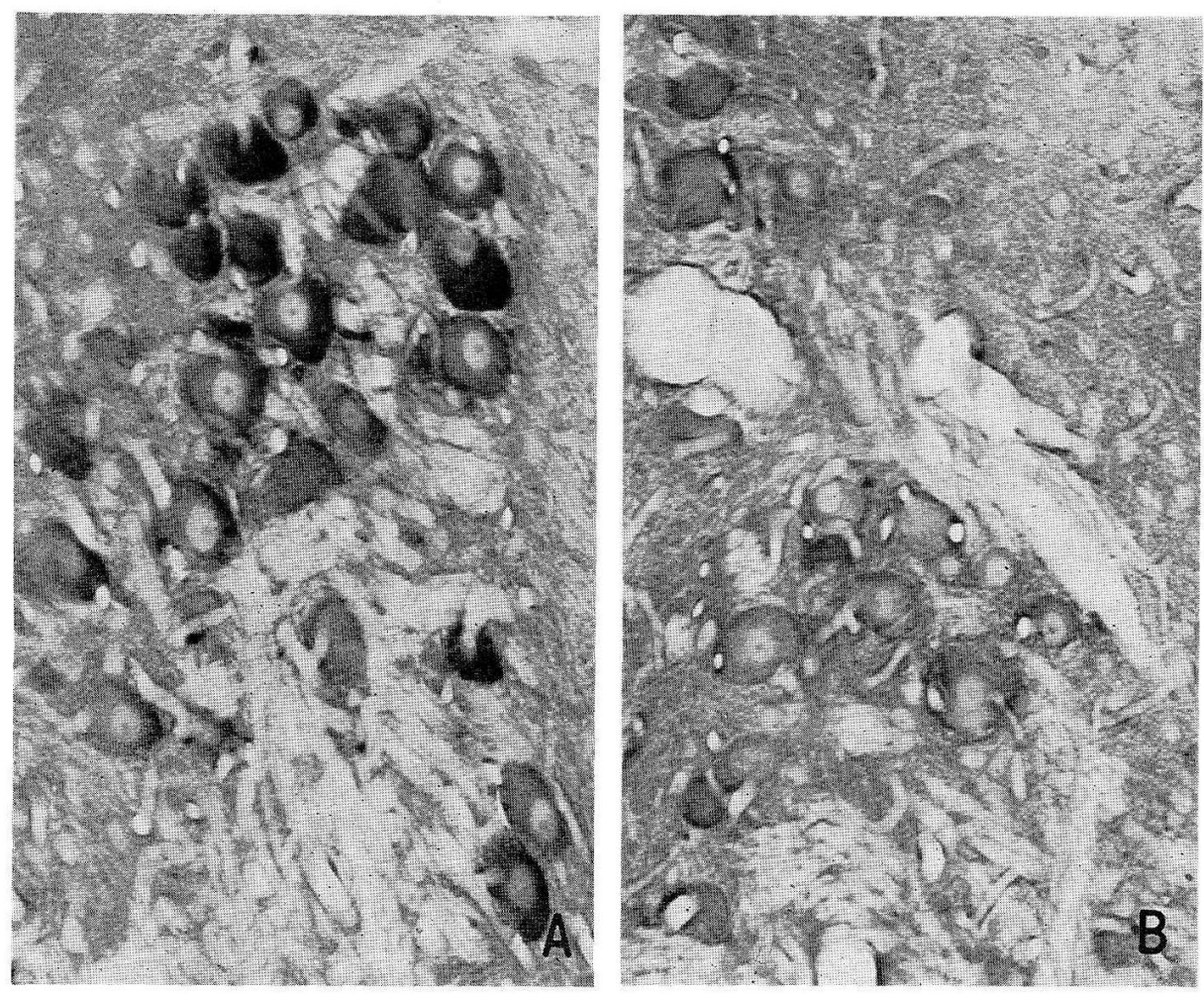

Fig. 2. PAS reaction in the mesencephalic nucleus, 16 hours after neurotomy of the trigeminal third division. A shows the control side and $\mathbf{B}$ the affected side. $\times 225$

showed a tendency to decrease in basophilia and they became smaller and smaller in size until they were less than one half of the average. It should be emphasized that the mesencephalic neurons evidently showed chromatolytic shrinkage following neurotomy of the dendritic afferent fibers. These neurons were characterized not only by irregular shrinkage but also by nuclear eccentricity. Small amounts of the Nissl substances were preserved in the limited area adjacent to the cell membrane and nuclear membrane of the severely damaged neurons. Already decreased PHO, UDPGGT and PAS reactions revealed no activity in these shrunken neurons except for a few small neurons and then this histochemical condition continued for about 20 days (Fig. 4). Even in this period, ALD and $\mathrm{LDH}$ reactions were well preserved in some neurons but mildly decreased in others (Fig. 5, 6). SDH activity was clearly 
decreased with cell shrinkage and it became weakest after 10 days (Fig. 7). On the other hand, G6PDH activity became stronger in the neurons and neuroglial cells after 10 days (Fig. 8). Though ACP reaction initially demonstrated numerous granular deposition, a few days later the cytoplasm of a shrunken neurons was compactly occupied with the homogenously reacting products. After 10 days, it became limited to the peripheral region of the shrunken neurons as shown in Figure 9B. The distribution of ACP seemed to correspond to the hyperchromic area adjacent to the cell membrane of shrunken neurons in the Nissl stained sections (Fig. 1B).
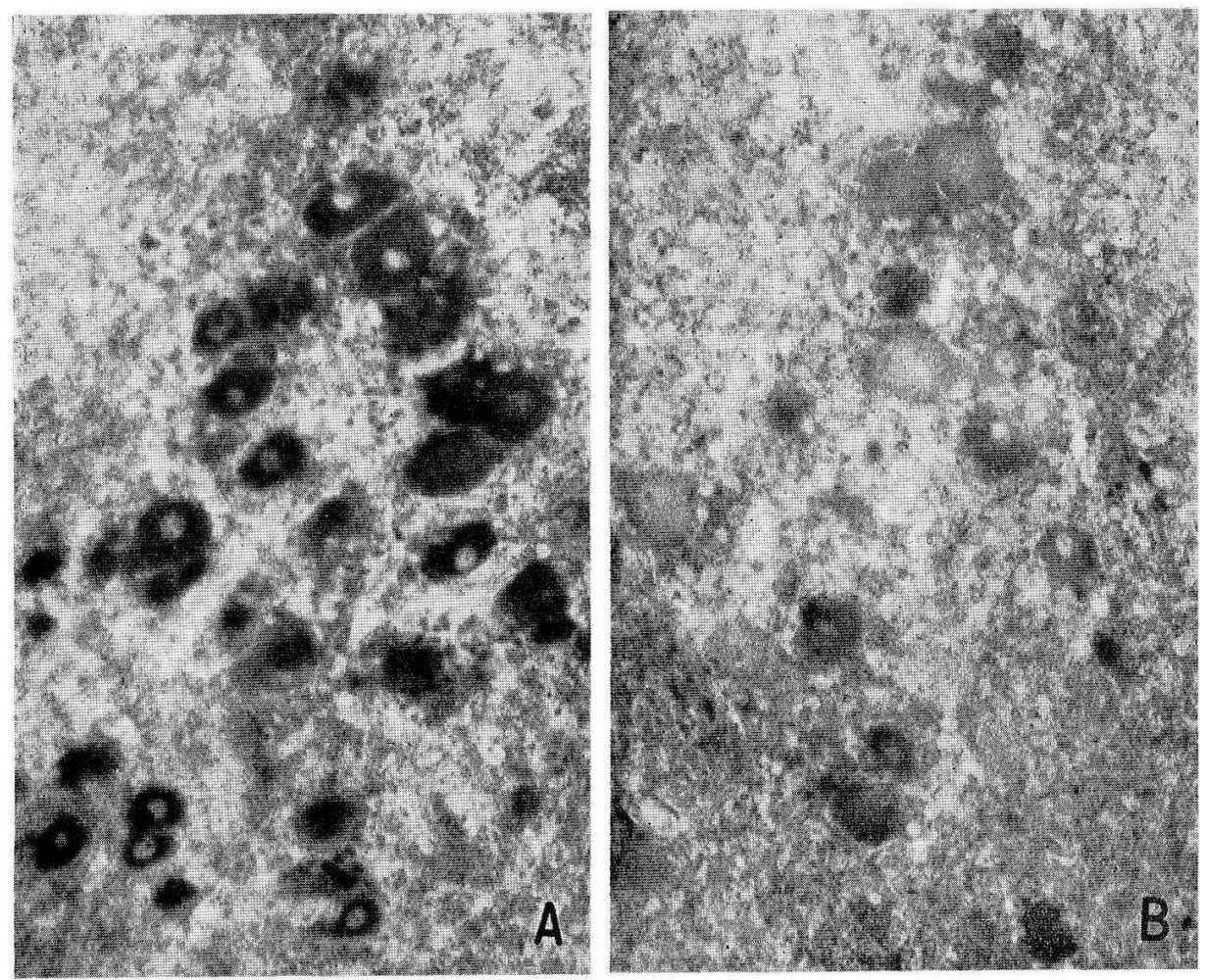

Fig. 3. Phosphorylase reaction in the mesencephalic nucleus, 16 hours after neurotomy of the trigeminal third division. A shows the control side and $\mathbf{B}$ the affected side. $\times 225$

From 20 days on after neurotomy, PHO began to exhibit weak activity again and a little later UDPGGT did also. Subsequently, the Nissl bodies seemed to be restored, but some neurons still showed a severe chromatolytic area. $\Lambda$ fter 80 days, some mesencephalic neurons revealed such a degree of recovery that the Nissl pattern was similar to normal granular type and uniform distribution in the cytoplasm, and the cell nucleus was observed to migrate into the central area of the neurons. However, the neurons in the affected side were rather small in size and the number of the neurons was decreased to about $75 \%$ of the control (about 950 cells by counting). Hence, the remaining neurons may re-establish the cellular function but one fourth of the mesencephalic neurons may become into necrotic. Histochemical reactions 
were slowly restored in keeping with the morphological reconstruction. By 80 days, both PHO and UDPGGT began to show considerable activity and P $\Lambda$ S positive substances also appeared in the cytoplasm, but the recovery of the histochemical changes in ALD, LDH and SDH reactions was not fully completed. G6PDH and ACP reactions showed somewhat higher activity than the control side even after 80 days. The neuropil of the mesencephalic nucleus was negligible in the morphological and histochemical events. However, it may be worth noticing that satcllitc cells, or neuroglial cells enclosing the neurons, were comparatively larger in number and seemed more positive in PAS reaction on the affected side. G6PDH and ACD were activated in some neuroglial cells of the affected side.
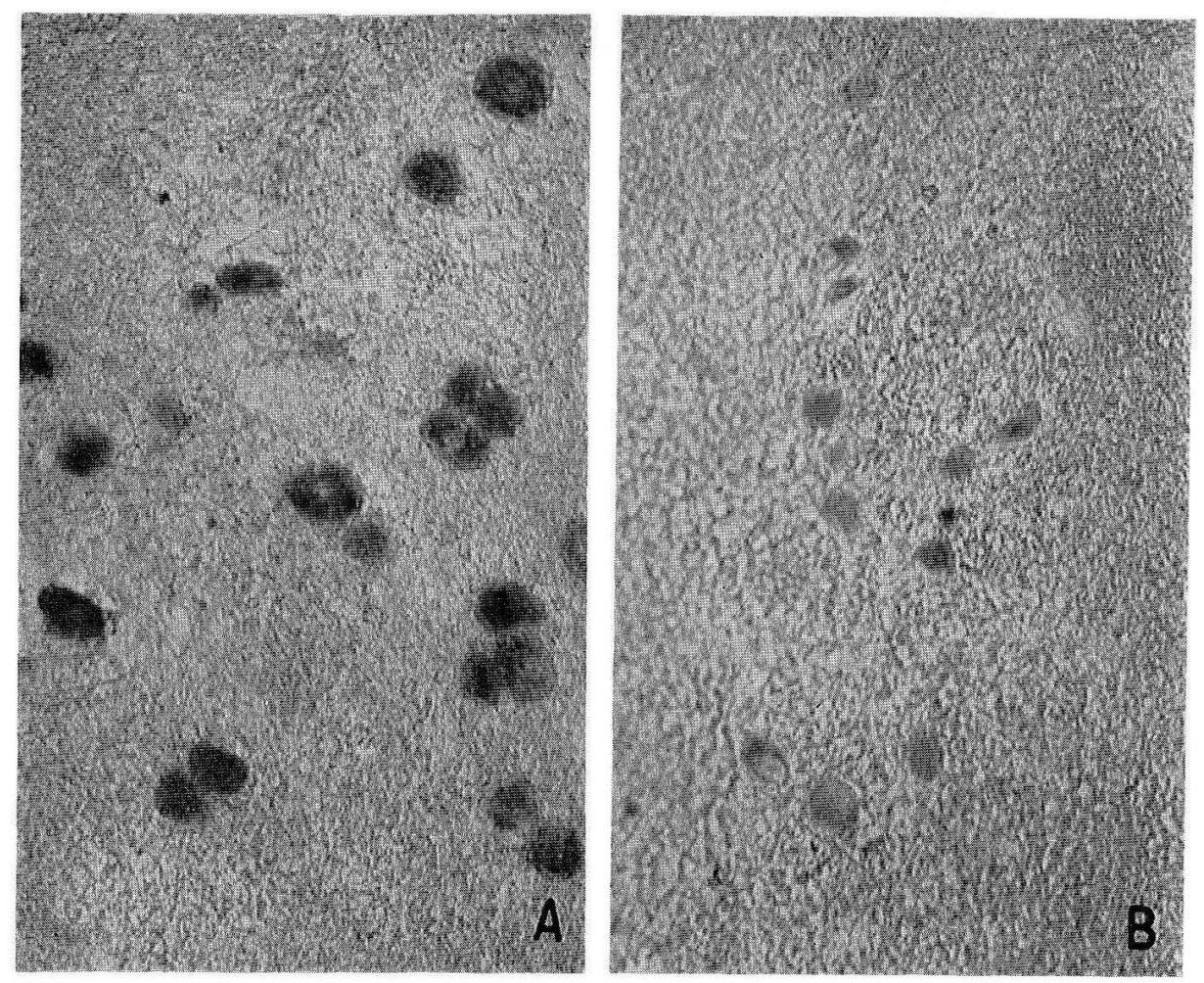

Fig. 4. UDPGGT-glycogen transferase reaction in the mesencephalic nucleus, 4 days after neurotomy of the trigeminal third division. A shows the control side and $\mathbf{B}$ the affected side. $\times 225$

\section{Changes in the motor nucleus}

Morphological changes in the motor nucleus were fairly different from those in the mesencephalic nucleus. They were so slight that the typical axonal reaction followed by central chromatolysis or nuclear eccentricity was not noticed. In the materials sacrificed after a few days the Nissl bodies had become smaller in size, and basophilic substances around the nucleus had become considerably homogenous. As soon as the third division of the trigeminal nerve was cut, G6PDH and ACP were activated. G6PDH was very strong throughout the cytoplasm and ACP was activated 
in the perinuclear region appearing as the reticular structures. The peak of both activities was on the 10 th day after the operation (Fig. 12, 13). In the motor neurons which cotained little PAS positive substances, PHO and UDPGGT did not show severe alteration. That was very different from the response to nerve injury of the mesencephalic neurons. PAS reaction was slightly increased in the neuroglial processes and around blood vessels from an early period. However, glycogen accumulation stopped in the later period, maintaining a little higher level in the affected side. The alterations of LDH, ALD and SDH activities in the neuropil deserve consideration now. Although these enzymes in the motor neurons showed no change, those in the neuropil distinctly showed a decrease. Namely, these activities became negative or very weak in the neuropil after 10 days as shown in Figures 10 and 11.
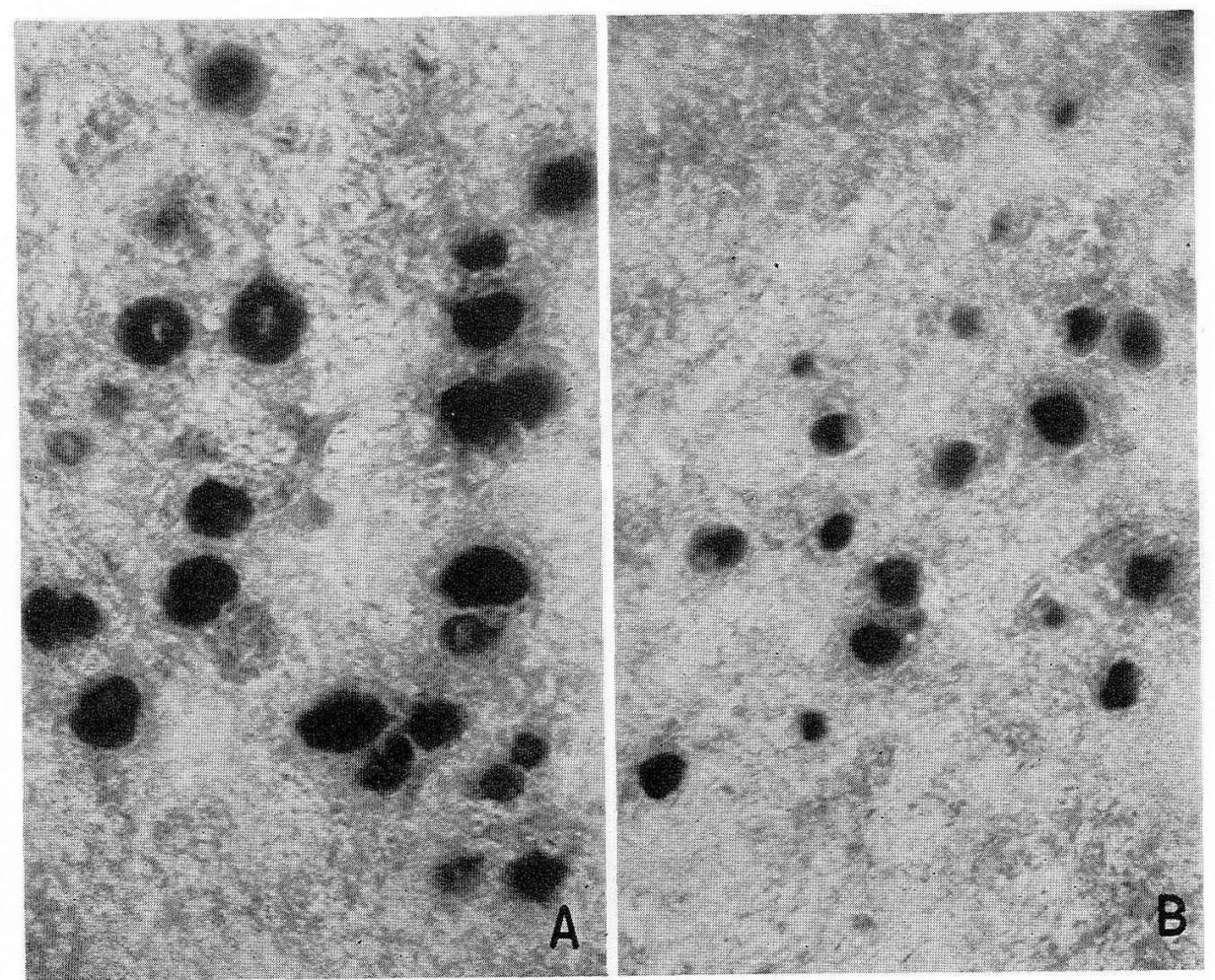

Fig. 5. Aldolase reaction in the mesencephalic nucleus, 10 days after neurotomy of the trigeminal third division. A shows the control side and $\mathbf{B}$ the affected side. $\times 225$

On the 80th day, G6PDH and ACP in the neuropil were still maintained higher than the control. In the neuropil of the motor nucleus, infiltration and multiplication of the glial cells were not particularly noticed except in a few cases. Some glial cells of the affected side were activated in $\mathrm{G} 6 \mathrm{PDH}$ and $\mathrm{ACP}$ reactions as well as the mesencephalic nucleus. 
K. Імамото:

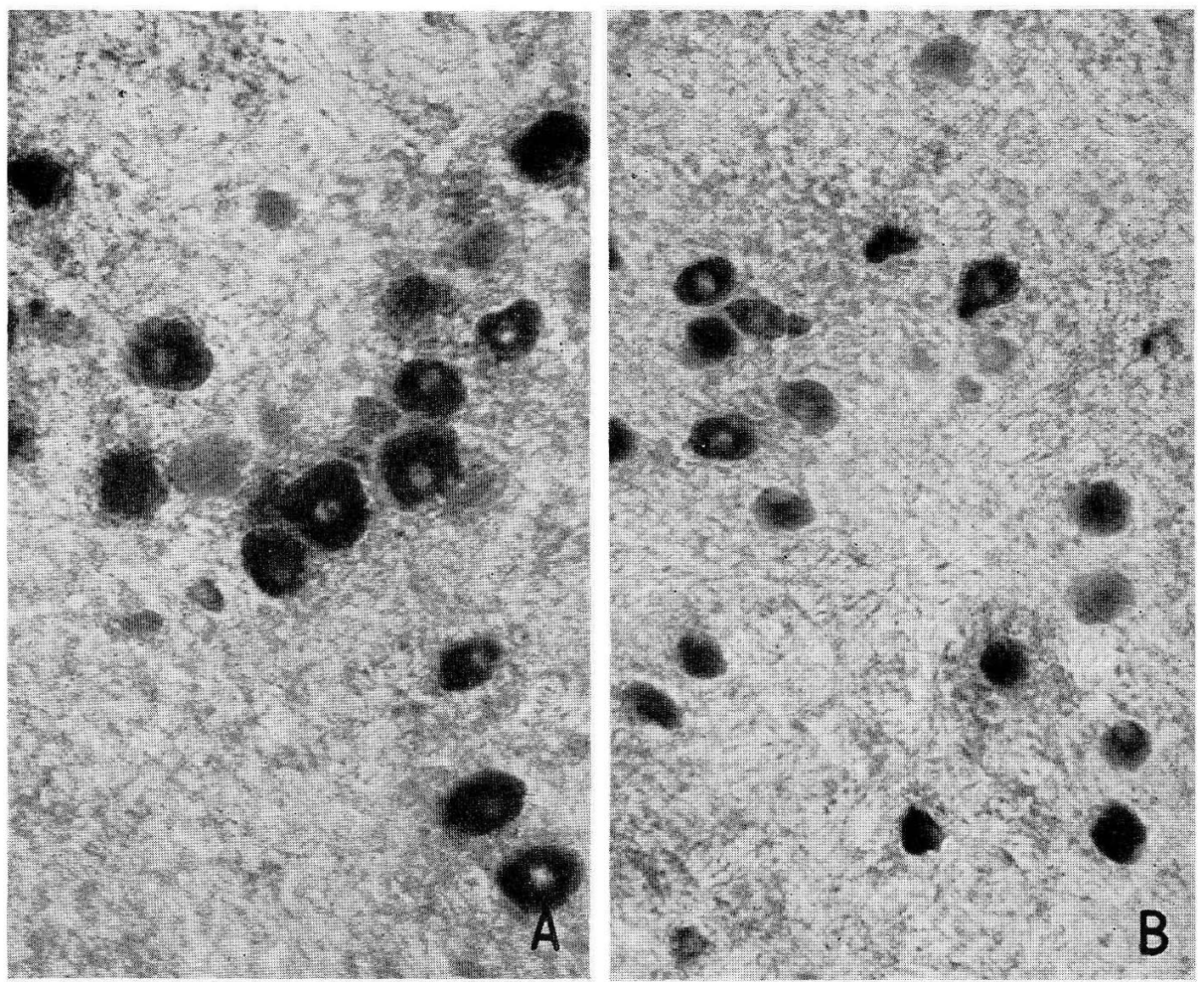

Fig. 6.
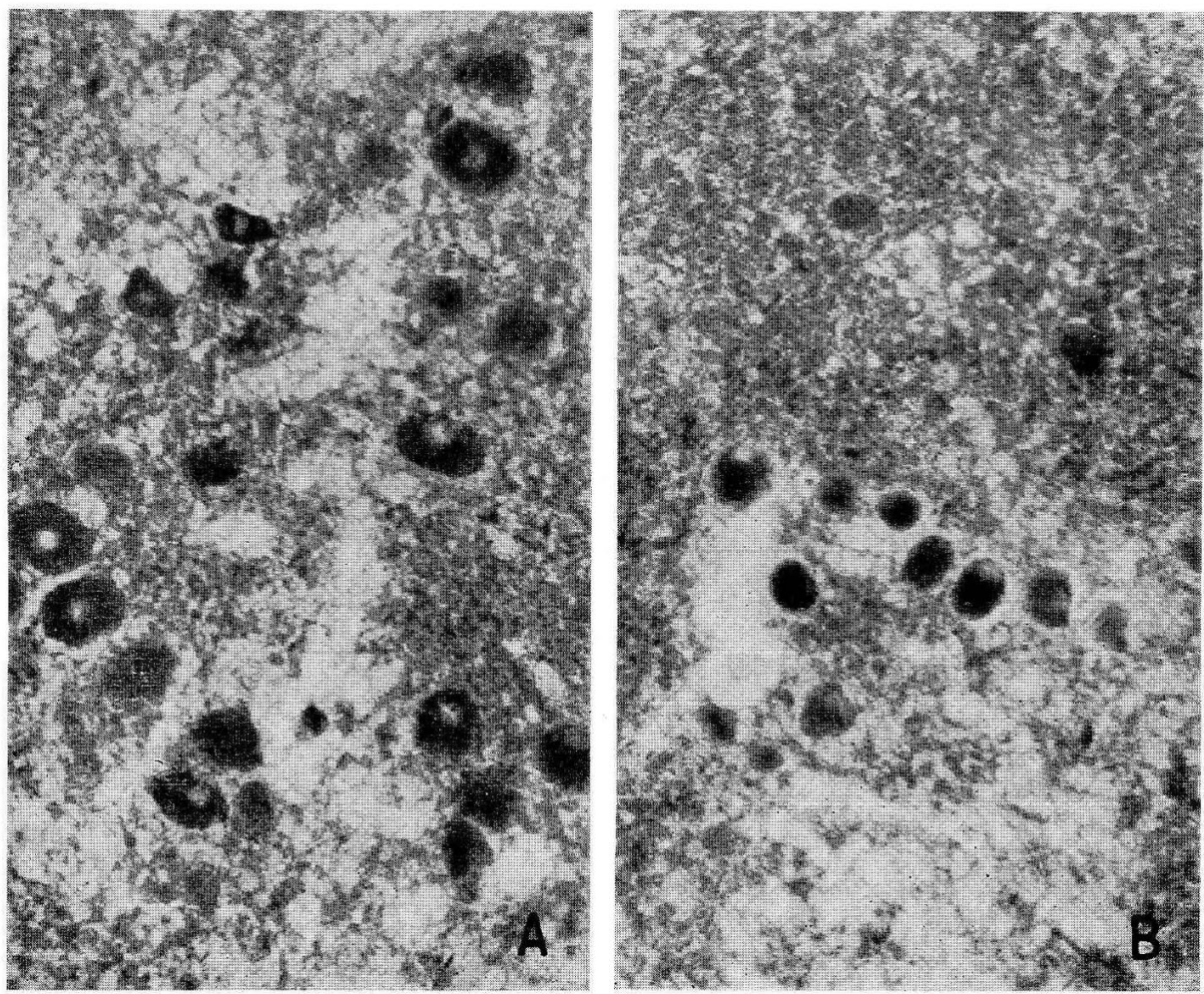

Fig. 7. 


\section{Discussion}

Morphological changes following neurotomy of the trigeminal nerve resulted in two different forms. In the mesencephalic nucleus they were characterized by cell shrinkage with central chromatolysis and in the motor nucleus by a mild swelling without chromatolysis. The facts may suggest that the intracellular response to nerve injury is quite different from nucleus to nucleus. Further the intensity of reaction to the trauma may be more serious in the proprioceptive afferent fibers than in the efferent fibers.
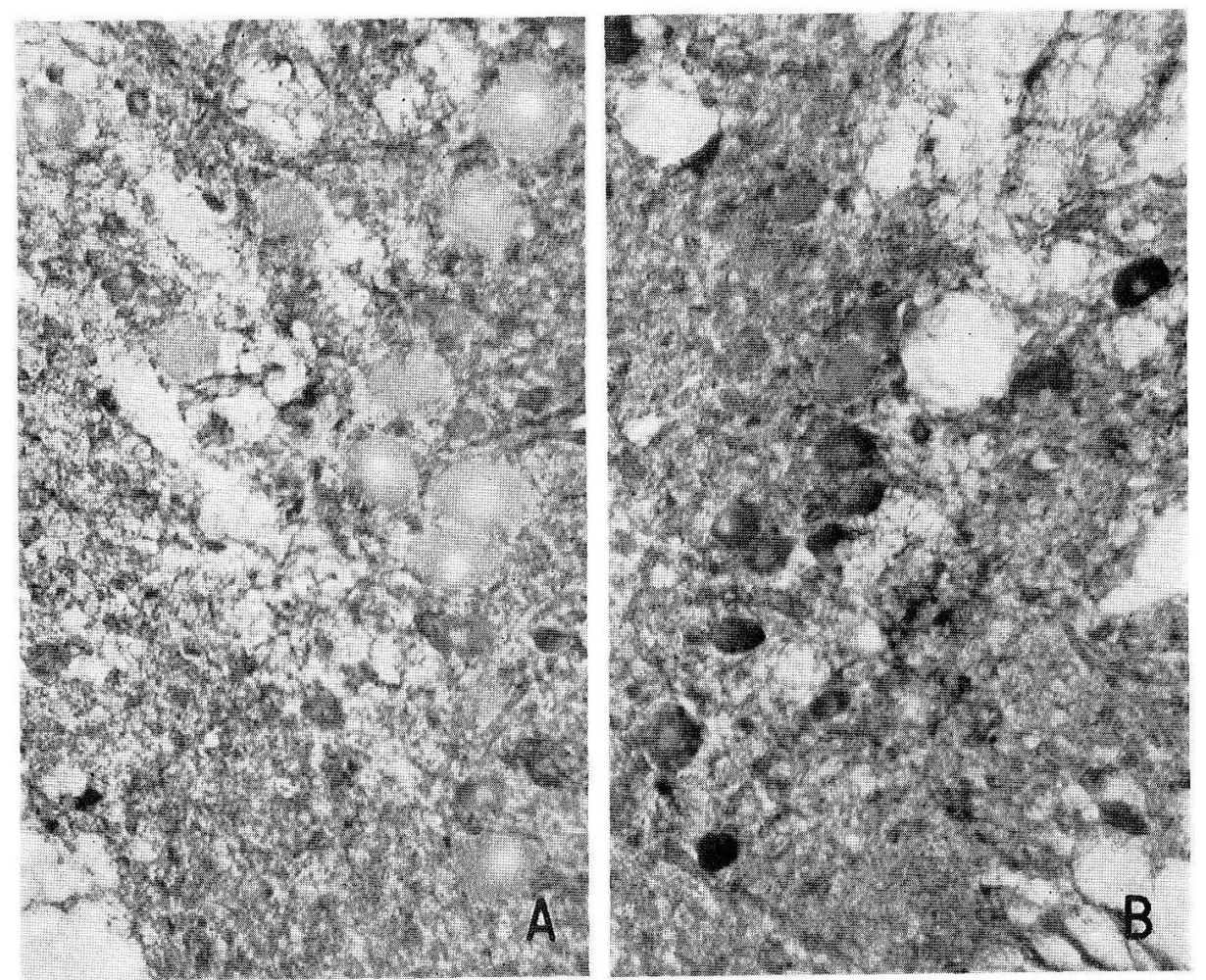

Fig. 8. Glucose-6-phosphate dehydrogenase reaction in the mesencephalic nucleus, 10 days after neurotomy of the trigeminal third division. Some neuroglial cells in $\mathbf{B}$ seem to be activated as well as the affected neurons. $\times 225$

Some investigators have considered that so-called chromatolysis with cell swelling was caused by hyperosmotic pressure owing to the dissolution of the Nissl bodies such as cytoplasmic RNA or nucleoproteins (GERSH and BoDIAN, 1943). On the other hand, it is said that the change in the aggregation of the Nissl bodies to small particles may be regarded as indicative of active protein synthesis (BRATTGARD et al.,

Fig. 6. Lactic dehydrogenase reaction in the mesencephalic nucleus, 10 days after neurotomy of the trigeminal third division. A shows the control side and $\mathbf{B}$ the affected side. $\times 225$

Fig. 7. Succinic dehydrogenase reaction in the mesencephalic nucleus, 10 days after neurotomy of the trigeminal third division. A shows the codtrol side and $\mathbf{B}$ the affected side. $\times 225$ 
K. Імамото:
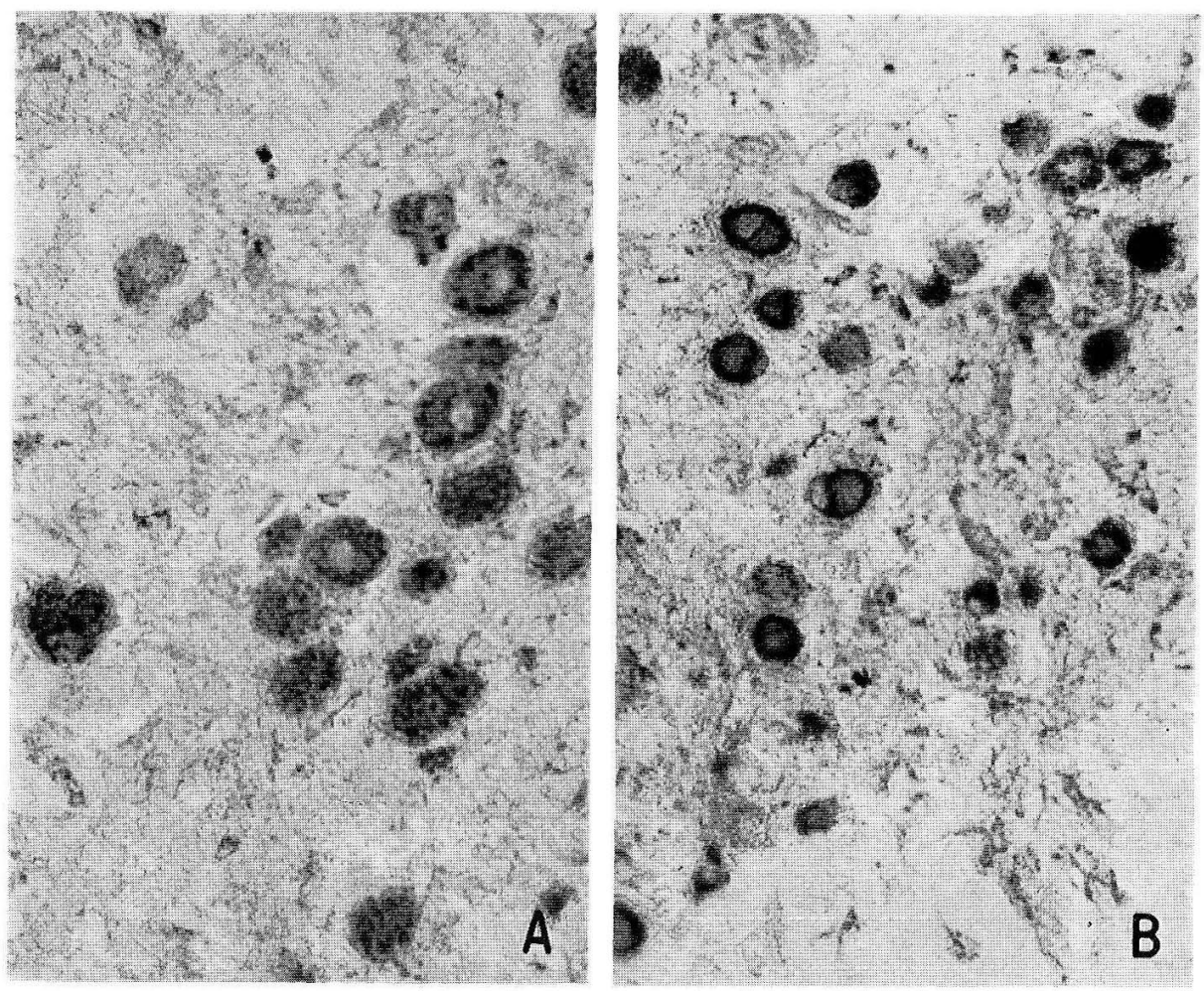

Fig. 9.
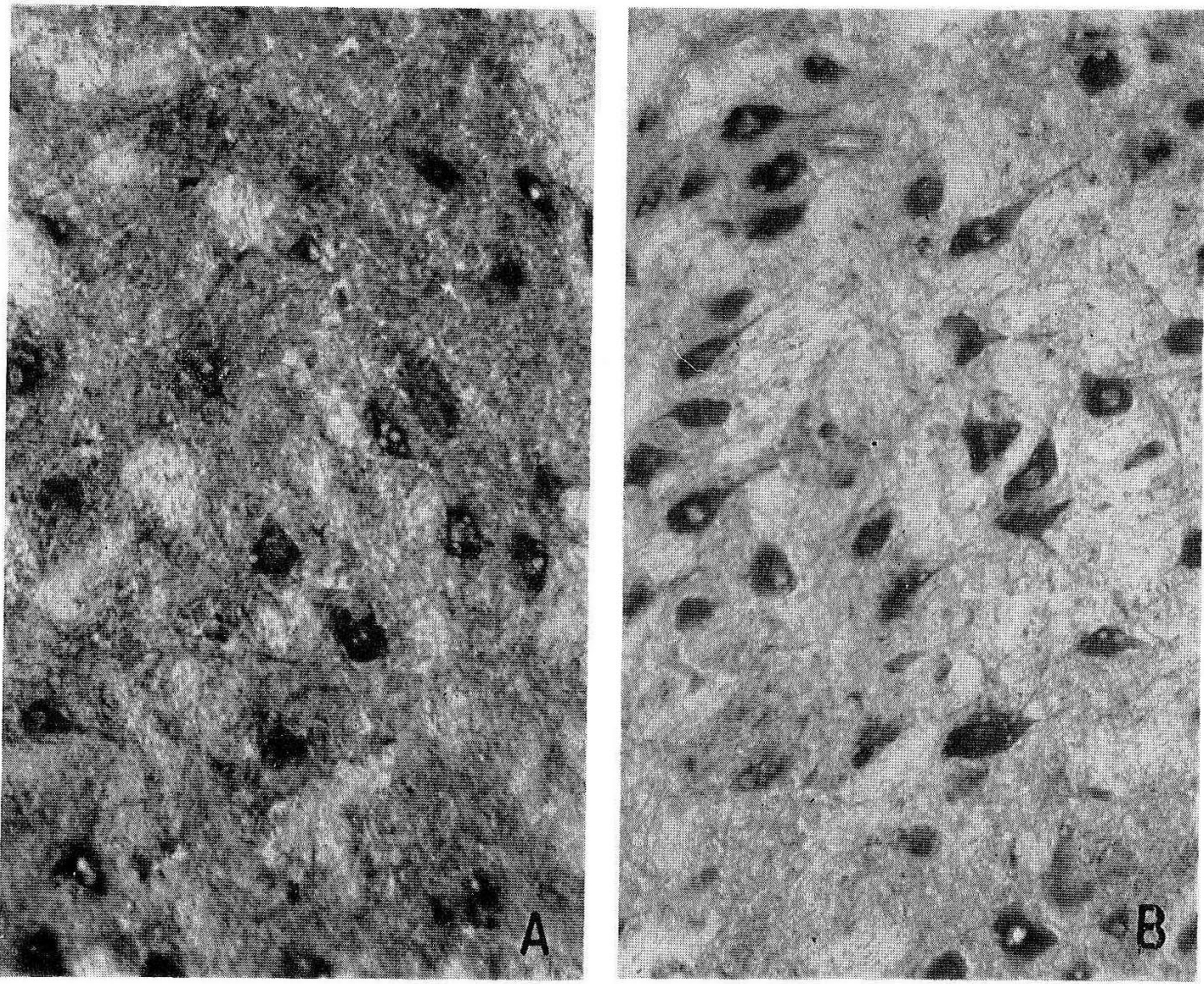
1957; Edström, 1959; Pannese, 1963; Barron et al., 1967), and that G6PDH activity in pentose phosphate shunt is deeply concerned with the synthesis of nucleic acids (BEACONSFIELD and READING, 1964). In this experiment, a chromatolytic change of the Nissl pattern with a marked increase of G6PDH activity was observed. In addition, ACP is also activated during the axonal reaction in both nuclei. Some workers have stressed the relationship between ACP and cytoplasmic RNA (BodIAN and MELIORS, 1945; LAVELLE et a1., 1954), and others reported correlation with lysosomes and Golgi apparatus (Barron and TuncBay, 1962; Dixon, 1967). Based on the distribution in the affected neurons, increased activity of ACP seemed to relate to depolymerization and turnover of cytoplasmic RNA as well as lysosomes and Golgi apparatus.
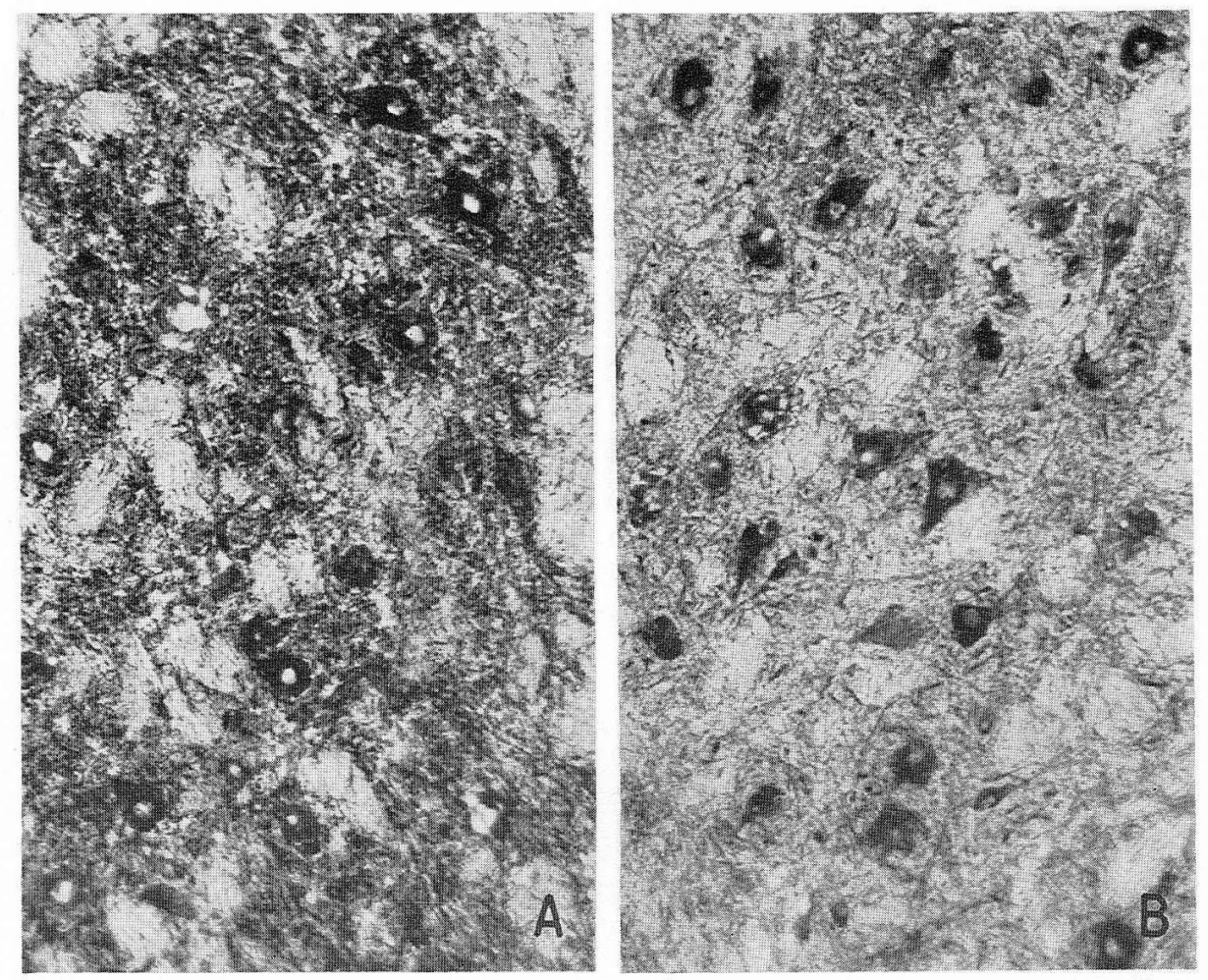

Fig. 11. Lactic dehydrogenase reaction in the motor nucleus, 10 days after neurotomy of the trigeminal third division. A shows the control side and $\mathbf{B}$ the affected side. $\times 225$

During the axonal reaction increased activities of G6PDH and ACP are frequently reported in histochemical works (KREUTZBERG, 1963; SHIMIzU, 1965; NANDy, 1968; Friede, 1966; Söderholm, 1965), while there are few reports on PHO and UDPGGT. PHO activity, however, exhibited the earliest and most noticeable changes in the mesencephalic neurons preceding the visible morphological changes. PHO

Fig. 9. Acid phosphatase reaction in the mesencephalic nucleus, 10 days after neurotomy of the trigeminal third division. A shows the control side and $\mathbf{B}$ the affected side. $\times 225$

Fig. 10. Aldolase reaction in the motor nucleus, 10 days after neurotomy of the trigeminal third division. A shows the control side and $\mathbf{B}$ the affected side. $\times 225$ 

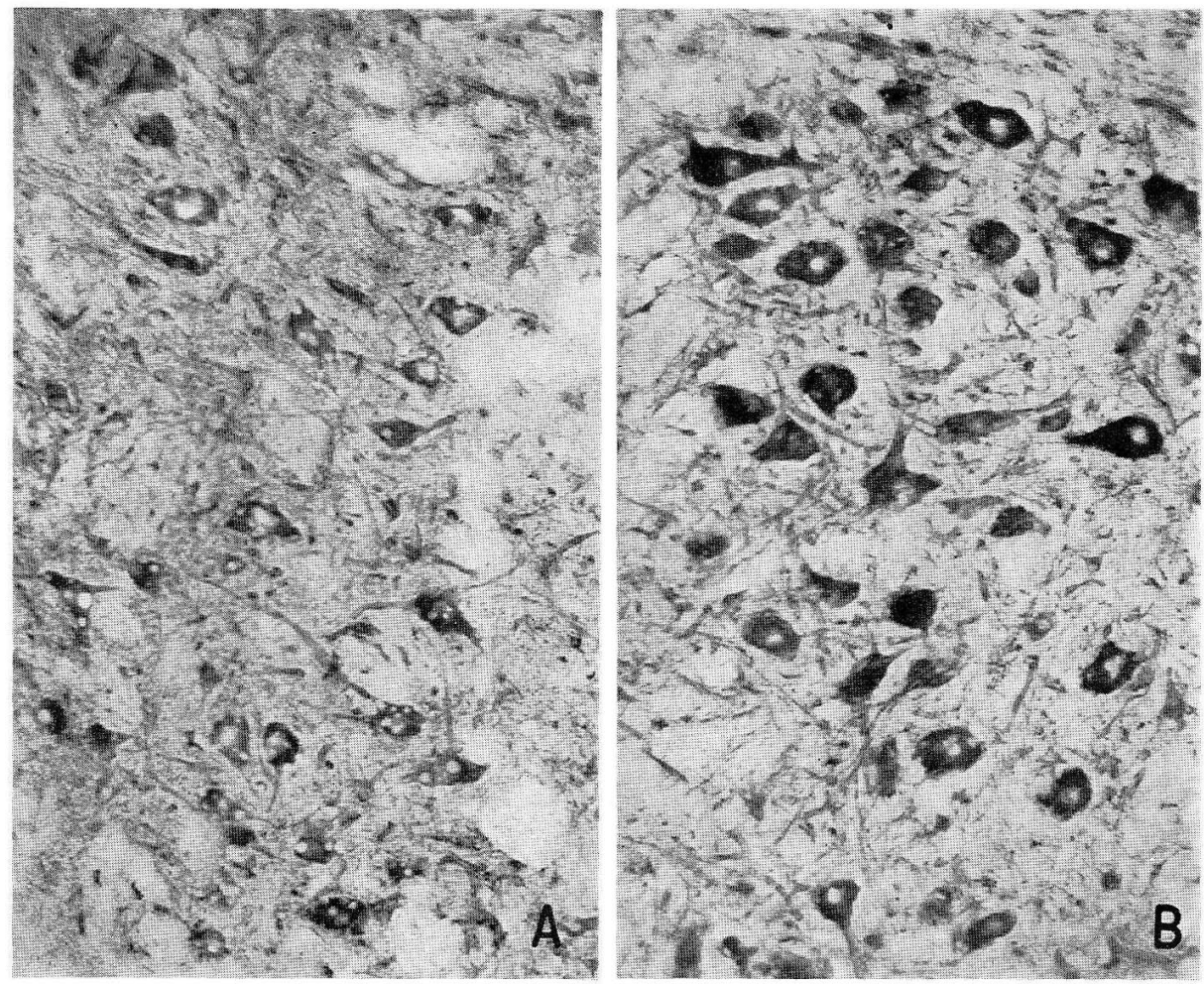

Fig. 12
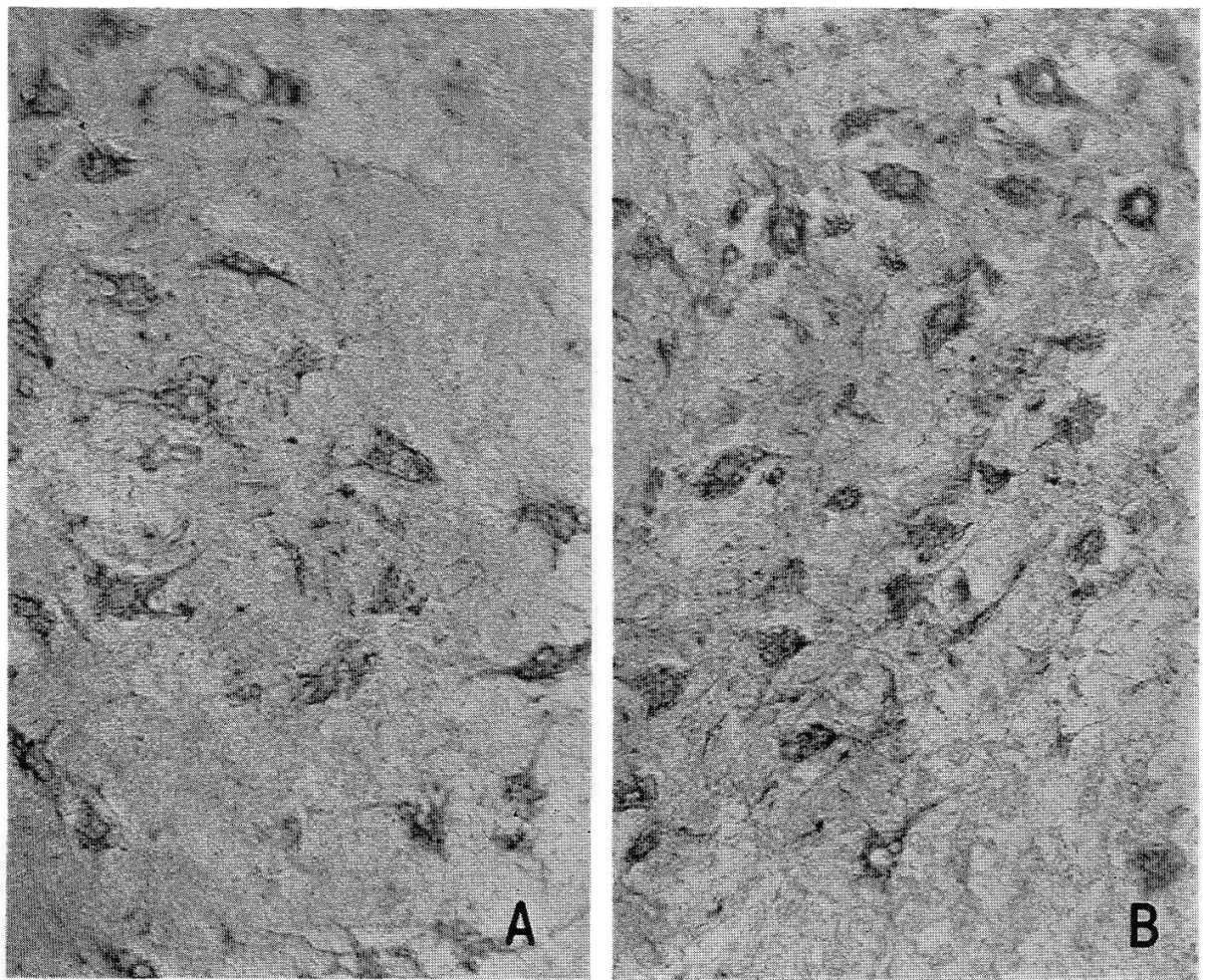

Fig. 13. 
showed temporarily increased activity till about $6 \mathrm{hrs}$ and was followed by sudden loss of it within $16 \mathrm{hrs}$ in the mesencephalic nucleus. Disppearaence of UDPGGT and PAS positive substances showed nearly identical alterations with PHO. In the anterior horn cells of the spinal cord, Murata (1959) reported a slight decrease in glycogen and phosphophorylase during 3 to 13 days of axonal reaction. The change in the mesencephalic nucleus occurs far earlier and more prominently than in MuRata's result and in that of the trigeminal motor nucleus. The reason for such an early shift in glycogenolysis and consumption of glycogen in the affected neurons is obscure. However, it seemed that the disappearence of PAS positive substances is concerned with the appearence of a non-basophilic area in the shrunken neurons of the mesencephalic nucleus. The changes in PHO and PAS reactions are probably attributable to the peculiarity of the mesencephalic nucleus. In these neurons stored a great deal of glycogen, and the alterations in $\mathrm{PHO}$ or PAS reaction may be regarded as sensitive parameters of the affected neuronal function.

It is interesting that the neuropil of the ipsilateral motor nucleus showed remarkable decrease in SDH, LDH and ALD activities, though the motor neurons showed only a slight decrease. Similar findings in the motor nucleus were recently obtained by Sнiмizu (unpublished) following destruction of the mesencephalic nucleus by localized electrolysis. In his case glycogen accumulation was observed in the neuropil of the motor nucleus as well. From these two experimental results, it is considered that the deafferentiation, either functional or morpholegical, might result in metabolic slowness and functional decrease of the synaptic area in the monosynaptic reflex arc. Functional decrease in collateral of the mesencephalic neurons may cause glycogen accumulation in the processes of astrocytes. The decrease in ALD, LDH and SDH activities was clearly observed in the perikaryon of the mesencephalic neurons. This result agreed with the reports by Kumamoto and Bourne (1963) and NANDY (1968) during axonal reaction but did not agree with Fischer and MALIK (1964) and Hamberger and Sjöstrand (1966).

Morphological and histochemical changes exclusively occurred in the nuclei of the ipsilateral side following neurotomy. The direct projection of the third division of the $V_{3}$ nerve to the central is surely unilateral, though Smith et al. $(1967,1968)$, Dault and Smith (1969) and Candiollo and Guglielmone (1970) argued bilateral innervation of the mesencephalic nucleus of the cat and rat.

Acknowledgement. The author would like to thank Prof. N. Shimizu for his helpful advice during this work.

\section{ラットの三叉神経第 3 枝切断後, その中脳路核と運動核に生じる組織化学的変化}

$$
\text { 今 本 喜久子 }
$$

ラットの左三叉神経第 3 枝を切断後, その中脳路核と運動核に生じる变化は, 同側性 であった。術後の形態的変化は 中脳路核では著しい細胞の萎縮と 核の偏在を伴うが,

Fig. 12. Glucose-6-phosphate dehydrogenase reaction in the motor nucleus, 10 days after neurotomy of the trigeminal third division. A shows the control side and $\mathbf{B}$ the affected side. $\quad \times 225$

Fig. 13. Acid phosphatase reaction in the motor nucleus, 10 days after neurotomy of the trigeminal third division. A shows the control side and $\mathbf{B}$ the affected side. $\times 225$ 
運動核では 軽度の膨大を示した. 中脳路核の組織化学的变化は術後 16 時間でフォス フォリラーゼ活性が急激に低下し, 前後して PAS 反応も消失することが特徴的であっ た. 一方 正常時, これらの反応が強くない運動核では 変化は不著明であった. グルコ ーズー6一憐酸脱水素酵素, 酸性フォスファターゼ活性は, 両核の神経細胞と神経膠細胞に おいて，術後10日目に強度の増強を示した。コハク酸脱水素酵素，アルドラーゼ，乳酸 脱水素酵素反応については 運動核細胞の变化は判然としないが，そのニューロピル（細 胞間隙) では 著明な活性低下が認められた。

\section{References}

Abe, T. and N. Shimizu: Histochemical method for demonstrating aldolase. Histochemie 4: 209-212 (1964).

Barron, K. D., P. F. Doolin and J. B. Oldershaw: Ultrastructural observations on retrograde atrophy of lateral geniculate body. J. Neuropathol. exp. Neurol. 26; 300-326 (1967).

Barron, K. D. and T. O. Tuncbay: Histochemistry of acid phosphatase and thiamine pyrophosphatase during axon reaction. Amer. J. Pathol. 40: 637-652 (1962).

Beaconsfield, P. and H. W., Reading: Pathways of glucose metabolism and nucleic acid synthesis. Nature 202: 464-466 (1964).

Bodian, D. and R. C. Mellors: The regenerative cycle of motoneurons with special reference to phosphatase activity. J. exp. Med. 81: 469-497 (1945).

Brattgård, S.-O., J.-E. Edström and H. Hydén: The chemical changes in regenerating neurons. J. Neurochem. 1: 316-325 (1957).

Candiollo, L. and R. Guglielmone: The effect of experimental removal of the tensor tympani muscle on the ipsi- and contralateral mesencephalic nuclei of the trigeminal nerve in the albino rat. Experientia 26: 997-998 (1970).

Cragg, B. G.: What is the signal for chromatolysis? Brain Res. 23: 1-21 (1970).

Dault, S. H. and R. D. Smith: A quantitative study of the nucleus of the mesencephalic tract of the trigeminal nerve of the cat. Anat. Rec. 165: 79-88 (1969).

Dixon, J. S.: "Phagocytotic" lysosomes in chromatolytic neurons. Nature (Lond.) 215: 657-658 (1967).

Edström, J.-E.: Ribonucleic acid changes in the motoneurons of the frog during axon regeneration. J. Neurochem. 5: 43-49 (1959).

Fischer, J. and V. Malik: A histochemical study on the effect of transsection of the facialis nerve on the picture of glycerophosphate, lactate, succinate, malate and glutaminate dehydrogenase in the cells of the facial nerve nucleus. Acta histochem. (Jena) 19: 369-376 (1964).

Friede, R. L.: Topographic brain chemistry. New York-London, Academic Press, 1966.

Geist, F. D.: Chromatolysis of efferent neurons. Arch. Neurol. Psychiat. 29: 88-103 (1933).

Gersh, I. and D. Bodian: Some chemical mechanisms in chromatolysis. J. cell. comp. Physiol. 21; 253-279 (1943).

Hamberger, $\mathbf{A}$. and $\mathbf{J}$. Sjöstrand: Respiratory enzyme activities in neurons and glial cells of the hyroglossal nucleus during nerve regeneration. Acta physiol. scand. 67: 76-88 (1966).

Imamoto, $\mathbf{K}$. and $\mathbf{N}$. Shimizu: Fine structure of the mesencephalic nucleus of the trigeminal nerve in the rats. Arch. histol. jap. 32: 51-67 (1970).

Kreutzberg, G. W.: Changes of coenzyme (TPN) diaphorase and TPN-linked dehydrogenase during axonal reaction of the nerve cell. Nature (Lond.) 199: 393-394 (1963).

Kumamoto, T. and G. H. Bourne: Experimental studies on the oxidative enzymes and hydrolytic enzymes in spinal neurons. Acta anat. 55: 255-277 (1963). 
LaVelle, A., C.-N. Liu and F. W. LaVelle: Acid phosphatase activity as related to nucleic acid in the nerve cell. Anat. Rec. 119: 305-323 (1954).

Maeda, T.: Experimental and histochemical studies on the hyperchromic neurons (in Japanese). Arch histol. jap. 27: 177-197 (1966).

Murata, Y.: Histochemical studies of spinal motor neurons in the axonal reaction (in Japanese). Med. J. Osaka Univ. 9: 3043-3049 (1959).

Nachalas, M. M., K. C. Tsou, E. D. Souza, C. S. Cheng and A. M. Seligman: Cytochemical demonstration of succinic dehydrogenase by the use of a new p-nitrophenyl substitued ditetrazole, J. Histochem. Cytochem. 5: 420-436 (1957).

Nachalas, M. M., D. G. Walker and A. M. Seligman: The histochemical localization of triphos phophyridine nucleotide diaphorase. J. biophys. biochem. Cytol. 4: 467-473 (1958).

Nakajima, Y.: Histochemical studies on carbohydrate metabolism of the mesencephalic nucleus of the trigeminal nerve in the rat. Bull. Tokyo Med. Dent. Univ. 12: 265-282 (1965).

Nandy, E.: Histochemical study on chromatolytic neurons. Arch. Neurons. 13: 425-434 (1968).

Pannese, E. Investigations on the ultrastructural changes of the spinal neurons in the course of axon regeneration and cell hypertrophy. Z. Zellforsch. 61: 561-586 (1963).

Shimizu, N.: Brain histochemistry (in Japanese). Brain and Nerve 17: 206-212 (1965).

Shimizu, N, and T. Abe: Histochemical studies of the brain with reference to glucose metabolism. Progr. Brain Res. 21: 197-216 (1966).

Shimizu, N. and H. Arizono: On the histochemical method of phosphatases (in Japanese). Seitai no Kagaku 1: 198-203 (1949).

Smith, R. D., H. Q. Marcarian and W. T. Niemer: Bilateral relationships of the trigeminal mesencephalic nuclei and mastication. J. comp. Neurol. 131: 79-92 (1967). nucleus. J. comp. Neurol. 133: 495-502 (1968).

Söderholm, U.: Histochemical localization of esterases, phosphatases and tetrazolium reductases in the motor neurons of the spinal cord of the rat and the effect of the nerve division. Acta physiol. scand. 65, Suppl. 256 (1965).

Szentágothai, J.: Anatomical considerations of monosynaptic reflex arcs. J. Neurophysiol. 2: $445-453$ (1948).

Takeuchi, T.: Histochemistry of intracellular polysaccharide synthesis. Ann. Histochem. 7: 61-79 (1962).

Takeuchi, T. and G. G. Glenner: Histochemical demonstration of a pathway for polysaccharide synthesis from uridine-diphosphoglucose. J. Histochem. Cytochem. 8: 227-230 (1960).

今本 喜久子

厂530 大阪市北区常安町 33

大阪大学医学部高次神経研究施設 解剖病理部門
Miss Kikuko Iмамото

Department of Neuroanatomy

Institute of Higher Nervous Activity

Osaka University Medical School

33 Joan-cho, Kita-ku, Osaka

530 Japan 